\title{
Economic Crisis in Europe: Panel Analysis of Inflation, Unemployment and Gross Domestic Product Growth Rates
}

\author{
Bibi Rouksar-Dussoyea ${ }^{1}$, Ho Ming-Kang ${ }^{1}$, Raja Rajeswari ${ }^{1} \&$ Benjamin Chan Yin-Fah ${ }^{1,2}$ \\ ${ }^{1}$ Faculty of Business and Management, Asia Pacific University of Technology \& Innovation (APU), Malaysia \\ ${ }^{2}$ Chair, Centre of Socioeconomic of Ageing (APU), Technology Park Malaysia, Kuala Lumpur, Malaysia \\ Correspondence: Benjamin Chan, Faculty of Business and Management, Asia Pacific University of Technology \\ \& Innovation (APU), Malaysia. Tel: 603-8989-6100. E-mail: Benjamin_chan@apu.edu.my
}

Received: July 27, 2017

Accepted: August 25, 2017

Online Published: September 10, 2017

doi:10.5539/ijef.v9n10p145

URL: https://doi.org/10.5539/ijef.v9n10p145

\begin{abstract}
This panel analysis study is conducted to examine the relationship between inflation rates (CPI) and unemployment rates (HUR) with the Gross Domestic Product growth rates (GDP), before and after the 2008 European crisis. Quarterly data for 18 consecutive years and six sample countries from Europe (Austria, France, Germany, Greece, Hungary and United Kingdom) have been considered in the panel. In order to get a more profound understanding of the impacts of the European crisis on the relationship between the variables, the panel data set has been classified into 3 separate panels, such that Panel 1 (1999Q1-2007Q4) represents before-crisis panel, Panel 2 (2008Q1-2016Q4) represents the during/after crisis panel and lastly, Panel 3 (1999Q1-2016Q4) represents the long-run panel. Panel 1 is subject to the Fixed Effects with LSDV model, whereby four out of the six countries are significant, and CPI and HUR are insignificant predictors of the GDP. Both Panel 2 and Panel 3 are subject to the Two-way Random Effects model, whereby both CPI and HUR have negative significant effect on GDP. Granger Causality test has also been carried out to determine whether causality is present among variables, based on each panel.
\end{abstract}

Keywords: panel analysis, OECD data, gross domestic product

\section{Introduction}

\subsection{Background of the Study}

The global financial crisis that started in the United States (US) around mid-2007 was due to a severe liquidity deficiency among financial institutions when they faced ever harsh market conditions while attempting to transfer short term debts. Consequently, insolvency among those institutions started to become a regular issue and shortly after, a major US investment bank called Lehman Brothers collapsed in September 2008. This resulted to a fall in the confidence level and pushed investors to substantially liquidate and close their positions, causing the stock market to plunge. As a result, the financial market of the European Union (EU) was knocked down to its lowest since the recession of 1930s (Great Depression). At this point of time, financial distress caught up the EU economy and eventually caused credit restraint and declining confidence among investors and consumers. In 2009, the contraction in real output (GDP) of EU was expected to be at 4\%, at its sharpest fall for the first time. The 2008 European crisis is also known as the 'Great Recession' (European Commission, 2009).

Incorrect market expectations and speculations following the European crisis were the main reasons behind the currency crisis and also the country's GDP growth was seen to be slow and the economy had a sluggish growth. (Dapontas, 2011). Recently, in the third quarter of 2016, as per (Fletcher, McDonald, \& Kasperkevic, 2016), it is found that Europe is facing a declining growth, together with rising inflation and stable unemployment.

Previous literature reviews are concerning the relationships of the variables of this study, European debt crisis of 2008 and its impacts on each of the six sample countries chosen. However, as it can be seen, the reviews are sometimes contradictive with other studies and therefore do not provide a clear image (Cuaresma \& Silgoner, 2013; Gillman, Harris, \& Matyas, 2002; Alias, Razak, Asari, \& Zin, 2011; David et al., 2005; Uz, Donghui, \& Imran, 2012; Neto \& Silva, 2013). The main objective of the study is to examine the relationship between inflation and unemployment rates with GDP growth rate, before and after the crisis. But the studies in the literature make use of different testing techniques, for distinct European countries, and also, not all of them shed 
light on the difference on the variables' relationship before and after the crisis. Most of the researches only focus on what happened after the crisis and do not reveal the difference between trends before crisis and now. So, to fulfill the gap that is present between the literature reviews and the objectives that the researcher wishes to achieve, this study has to be carried forward so that the research questions may be answered in a clearer way. This research will therefore make use of more specific techniques including panel data analysis and causality tests; so that the relationships that exist between the three variables can be studied for a longer term, taking into consideration trends before and after crisis?

It is to be noted that these six countries are all members of the European Union (EU). The EU represents the union of 28 European countries, acting as a single market without trade barriers. The EU intends to reinforce Europe's trading prospects and its political and economic significance, on a global basis (Cia.gov, 2017). Also, the six countries are all members of the OECD (Organization for Economic Co-operation and Development) countries. This findings provides an insight to potential investors who wish to comprehend the economy before taking any step. For instance, this might be an aid to other economies who wish to trade with countries inside the European boundary, for example, by making them aware as of when it is the best economic period for trade to take place. In addition, denoting the link between the three economic variables will allow other researchers to apply the knowledge obtained in their study, even though their research may be subject to the same variables being studied in different countries or during a different time period.

\section{Literature Review}

\subsection{Inflation, Unemployment and GDP Growth Rates}

According to Alias et al. (2011), who used multivariate time series analysis in his research, inflation rate affects GDP only in the short run and no correlation is found in the long run. The study also tested for causality by the Granger test and it was found that the relationship between inflation and GDP is unidirectional in the short run. As per stated by Mallik and Chowdhury (2001 cited in Alias et al., 2011), some economists argue that inflation is vital for economic growth, that is GDP growth; and on the other hand, the rest argue for the contrary. In addition, according to Cuaresma and Silgoner (2013), who tested for the multiple linear relationship on 14 European Union countries, inflation and growth is positively related when inflation rates are low and tend to be insignificant or negatively correlated when inflation rates are high. The same argument is supported by Gillman, Harris and Matyas (2002), who tested for correlation between the variables, stating a positive inflation-growth relationship for low inflation rates and negative relationship at higher level of inflation with a sample of 29 OECD (Organization for Economic Co-operation and Development) countries. However, in contrast to what was stated by Alias et al. (2011), another research by David et al. (2005) states that there exists a relationship between inflation and growth both in the long-run and short run. David et al. (2005) used econometric techniques to examine their panel data that includes a sample of 138 countries. Therefore, as it can be seen, the previous studies generate contradicting types of relationships. This is because they made use of different methods, different sample countries and different time periods and therefore came out with different results. Hence, study aims to verify whether there is a significant relationship between inflation rate and Gross Domestic Product (GDP) growth rate, based on a sample data in Europe, before and after the 2008 economic crisis.

In a research carried out by Zagler (2003), which used four European countries (including France, Germany, Italy and UK), and made use of the Dickey-Fuller test for stationarity testing and also used the co-integration test; it was concluded that in the short term, rising unemployment rates results in a fall in growth rates; whereas in long term, there is a positive correlation between growth and unemployment rates. In addition, a panel data analysis by Uz, Donghui and Imran (2012) that used a sample of 13 European countries for the years 1993 to 2012 and methods such as Pooled OLS and Fixed effect in their research, concluded that GDP per capita is negatively and significantly affected by higher unemployment rates. According to a Bibliometric analysis conducted by Neto and Silva (2013), a positive correlation characterizes the relationship of GDP growth and unemployment rates. The given reason for this conclusion is explained by the fact that increase in growth rates triggers a wage rise which eventually contributes to further increase the level of unemployment. Moreover, as per Levine (2013), changes between unemployment rates and real output growth are negatively related and unemployment recovery after recession tends to be slow. Another panel data analysis conducted by Göçer and Erdal (2015), which tested for co-integration, states that no matter how good the GDP growth of European countries is, it will not be sufficient to decrease the unemployment level among its youth, unless effective policies are implemented in the country.

Based on the prior researches, it is still difficult to validate the type of relationship between unemployment rate and Gross Domestic Product (GDP) growth rate. This is because they made use of different methods, different 
sample countries and different time periods and therefore came out with different results. Thus, the second specific aim of this study is to verify and ascertain whether there is a significant relationship between these two variables, pertaining to a sample from six European countries, before and after the 2008 crisis.

\subsection{Theoretical Assumptions}

Philips Curve Theory and Okun's Law Theory provides the basic for this study. The Philips curve theory was initially developed and proposed by a British economist, A. W. Philips in 1958, after examining the relationship between inflation and unemployment for past years. Since its release, the theory became a fundamental instrument used in subjects related to Macroeconomics and also, in the analysis of financial markets and economic systems. The theory suggests that inflation and unemployment follow a consistently inverse relationship. In other words, as inflation increases, unemployment falls and vice versa. The main reason behind rise in inflation when unemployment decreases, is associated with 'Wage inflation' and the inverse relationship between inflation and unemployment generates a downward sloping curve which is known as the Philips Curve.

The Okun's Law of unemployment is derived by the economist Okun around 1962. The economist found an inverse relationship between the growth rate of total output (GDP) and the unemployment rate at its natural rate. It was found that for each unit of percentage rise (fall) in the unemployment rate from its natural level; GDP would be decreased (increased) by two percent from its potential level (Research.stlouisfed.org, 2012)

\section{Method}

The collection of secondary datasets has been made from the OECD data bank. Firstly, the data source for quarterly GDP growth rate from the OECD statistics is "Quarterly National Accounts". Secondly, the data source for the quarterly (harmonized) unemployment rate from OECD data is from "Labour market statistics". Lastly, the data source for the quarterly inflation rate from OECD data bank is from "Consumer prices". The quarterly data for each variable were collected for six European countries, namely Austria, France, Germany, Greece, Hungary and United Kingdom (UK). The sample data selected for this study are the quarterly indexes ranging from the first quarter of 1999 to the fourth and last quarter of 2016. Therefore, the sample size amounts to 1296 observations, entailing quarterly data for 18 consecutive years, from 6 distinct European economies, for the 3 variables. Specific tests will be carried out to ensure that the data follows the required trends and respects the assumptions of the model. Granger Causality test, will also be used to determine causality among the variables for panel data before and after crisis. Based on the definitions taken from (Baltagi, 2008), this study is based on a balanced panel data analysis because the dataset of this study does not contain any missing values; and the structure of this dataset follows that of a long panel because the number of years (T) is greater than the number of individuals, that is countries $(\mathrm{N})$. This study has employed four ways to analyze a panel data, namely (1) Pooled OLS (Ordinary Least Squares) model, (2) Fixed Effects LSDV (Least Squares Dummy Variable) model; (3) Fixed Effects within-group model (FEM) and, (4) Random Effects Model (REM).

The software programmes which will be used to perform data analysis of this research include R-program (Version 3.4.0), SPSS and E-Views. The sample secondary data of 1,296 observations, consisting rates of inflation, unemployment and GDP growth will be keyed in. Consequently, the multiple tests required will be carried out so that the research questions can be answered. To be specofoc, simple descriptive statistics will be generated using SPSS; panel data analysis will be carried out using the R software while Granger causality tests will be executed in E-Views.

\section{Results}

The sample data entails observations of the three variables, collected for 18 years from 1999 to 2016, on a quarterly basis. In order to get a more thorough understanding of the data patterns being studied, the quarterly data of this study will be separated into three panels which will be classified as follows:

Panel 1 (1999-2007): Panel 1 consists of observations pertaining to data before the 2008 European crisis and therefore entails data for the first nine years for the six countries (totaling to 216 observations). So, Panel 1 might also be referred as 'Before Crisis Panel'.

Panel 2 (2008-2016): Panel 2 consists of observations pertaining to data during and after the 2008 European crisis and therefore entails data for the next 9 years for the 6 countries (totaling to 216 observations). So, Panel 2 might also be referred as 'During/After Crisis Panel'.

Panel 3 (1999-2016): Panel 3 consists of observations pertaining to data both before and after the 2008 European crisis and therefore entails data for the whole 18 years for the six countries from the sample (totaling to 432 observations). It can be noted that Panel 3 can be used to analyze data patterns in the long run, rather than just before or after crisis. So, Panel 3 might also be referred as 'Long-run Panel'. 
Table 1. Panels description

\begin{tabular}{lcc}
\hline PANELS & Other names & Time Period (Years/Quarterly) \\
\hline Panel 1 & Before crisis Panel & $1999-2007$ \\
Panel 2 & During/After crisis Panel & $2008-2016$ \\
Panel 3 & Long-run Panel & $1999-2016$ \\
\hline
\end{tabular}

In this section, the summary for descriptive of GDP, HUR and CPI across panels will be discussed. So, to get a brief and simple statistical overview of the panels, for each panel, the variables mean will first be observed

Table 2. GDP across panels' descriptive statistics

\begin{tabular}{cccccccccc}
\hline GDP & $\mathrm{N}$ & Range & Minimum & Maximum & \multicolumn{2}{c}{ Mean } & \multicolumn{2}{c}{ Std. Deviation } & Variance \\
across panels & Statistic & Statistic & Statistic & Statistic & Statistic & Std. Error & Statistic & Statistic \\
\hline Panel 1 GDP & 216 & 4.4540 & -1.2252 & 3.2289 & .693651 & .0427660 & .6285293 & .395 \\
Panel 2 GDP & 216 & 7.5249 & -4.7584 & 2.7665 & .017575 & .0740326 & 1.0880521 & 1.184 \\
Panel 3 GDP & 432 & 7.9873 & -4.7584 & 3.2289 & .355613 & .0456982 & .9498192 & .902 \\
\hline
\end{tabular}

The table above has been generated by SPSS in order to differentiate between some basic descriptive statistics of GDP across each panel. So, as it can be observed, the minimum, that is, the smallest growth in GDP observed was during Panel 2, that is, during or after crisis, denoted by $-4.7584 \%$. On the other hand, the maximum growth observed was during Panel 1, that is, before crisis, denoted by 3.2289\%. Also, the mean GDP of Panel 1 is greater compared to that of Panels 2 and 3. Moreover, the standard deviation and variance were highest during the after crisis Panel, since this is when more drastic changes took place.

Table 3. HUR across panels' descriptive statistics

\begin{tabular}{|c|c|c|c|c|c|c|c|c|}
\hline \multirow[t]{2}{*}{ HUR across panels } & \multirow{2}{*}{$\begin{array}{c}\mathrm{N} \\
\text { Statistic }\end{array}$} & \multirow{2}{*}{$\begin{array}{c}\text { Range } \\
\text { Statistic }\end{array}$} & \multirow{2}{*}{$\begin{array}{l}\text { Minimum } \\
\text { Statistic }\end{array}$} & \multirow{2}{*}{$\begin{array}{c}\text { Maximum } \\
\text { Statistic }\end{array}$} & \multicolumn{2}{|c|}{ Mean } & \multirow{2}{*}{$\begin{array}{c}\text { Std. Deviation } \\
\text { Statistic } \\
\end{array}$} & \multirow{2}{*}{$\begin{array}{l}\text { Variance } \\
\text { Statistic }\end{array}$} \\
\hline & & & & & Statistic & Std. Error & & \\
\hline Panel 1 HUR & 216 & 8.7000 & 3.6333 & 12.3333 & 7.457716 & .1552814 & 2.2821612 & 5.208 \\
\hline Panel 2 HUR & 216 & 23.9333 & 3.9000 & 27.8333 & 9.284259 & .3946061 & 5.7995017 & 33.634 \\
\hline Panel 3 HUR & 432 & 24.2000 & 3.6333 & 27.8333 & 8.370988 & .2163041 & 4.4957957 & 20.212 \\
\hline
\end{tabular}

The table above has been generated by SPSS in order to differentiate between some basic descriptive statistics of unemployment rates across each panel. So, as it can be observed, the minimum, that is, the smallest unemployment rate observed was during Panel 1, that is, before crisis, denoted by $3.63 \%$. On the other hand, the maximum unemployment rate observed was during Panel 2 that is, during/after crisis, denoted by 27.83 \%. Also, the mean unemployment rate of Panel 2 is greater compared to that of Panels 1 and 3. Moreover, the standard deviation and variance were highest during the after crisis Panel, since this is when more drastic changes took place.

Table 4. CPI across panels' descriptive statistics

\begin{tabular}{cccccccccc}
\hline CPI across panels & $\mathrm{N}$ & Range & Minimum & Maximum & \multicolumn{2}{c}{ Mean } & \multicolumn{2}{c}{ Std. Deviation } & \multicolumn{2}{c}{ Variance } \\
& & Statistic & Statistic & Statistic & Statistic & Statistic & Std. Error & Statistic & Statistic \\
\hline Panel 1 & CPI & 216 & 10.5774 & .1989 & 10.7763 & 2.761902 & .1514201 & 2.2254125 \\
Panel 2 & CPI & 216 & 9.2834 & -2.3779 & 6.9055 & 1.777365 & .1231375 & 1.8097439 & 3.275 \\
Panel 3 & CPI & 432 & 13.1542 & -2.3779 & 10.7763 & 2.269634 & .1003139 & 2.0849849 & 4.347 \\
\hline
\end{tabular}

The table above has been generated by SPSS in order to differentiate between some basic descriptive statistics of inflation rates across each panel. So, as it can be observed, the minimum, that is, the smallest inflation rate observed was during Panel 2, that is, during/after crisis, denoted by $-2.3779 \%$. On the other hand, the maximum inflation rate observed was during Panel 1 that is, before crisis, denoted by $10.77 \%$. Also, the mean inflation rate of Panel 1 is greater compared to that of Panels 2 and 3. Moreover, the standard deviation and variance were lowest during the during/after crisis Panel, since this is when suppliers and governments are more cautious to cause any drastic change in the general price level.

Four methods to be attempted in this study are Pooled OLS, Fixed Effects with LSDV, Fixed (within) Effects 
model, and Random Effects model. The pooled OLS method analyzes the group effects with constant slope coefficient, to see whether unemployment rate (HUR) and inflation (CPI) affect the dependent variable, GDP. Meanwhile, the Fixed effects LSDV method analyzes the individual country effects with constant slope coefficient, to see whether unemployment rate (HUR) and inflation (CPI) affect the dependent variable, GDP.

The one-way fixed effect method analyzes the fixed individual (country) effects, to see whether unemployment rate (HUR) and inflation (CPI) affect the dependent variable, GDP. But the one-way random effect method analyzes the random individual (country) effects, to see whether unemployment rate (HUR) and inflation (CPI) affect the dependent variable, GDP. Besides, the two-way fixed method considers both fixed time and country effect. But, for the two-way random method considers both fixed time and random country effect. All the panel data method has been carried out in $\mathrm{R}$ programming. The summary for models of each panel and overall summary for the data analysis are given in the Table 5 and Table 6 respectively.

Table 5. Summary for models of each panel

\begin{tabular}{|c|c|c|c|c|c|c|}
\hline Panel & Pooled OLS & $\begin{array}{c}\text { Fixed effect } \\
\text { LSDV }\end{array}$ & $\begin{array}{c}\text { One-way fixed } \\
\text { effect }\end{array}$ & $\begin{array}{c}\text { One-way } \\
\text { random effect }\end{array}$ & $\begin{array}{c}\text { Two-way fixed } \\
\text { effect }\end{array}$ & $\begin{array}{c}\text { Two-way random } \\
\text { effect }\end{array}$ \\
\hline 1 & Insignificant & $\begin{array}{l}\text { Significant with } \\
\text { high R-square }\end{array}$ & Insignificant & Insignificant & - & - \\
\hline 2 & $\begin{array}{l}\text { Significant but } \\
\text { very low } \\
\text { R-square value }\end{array}$ & $\begin{array}{c}\text { Significant but } \\
\text { low R-square } \\
\text { value }\end{array}$ & $\begin{array}{c}\text { Significant but } \\
\text { low R-square } \\
\text { value }\end{array}$ & $\begin{array}{c}\text { Significant but } \\
\text { low R-square } \\
\text { value }\end{array}$ & $\begin{array}{l}\text { Significant with } \\
\text { high R-square, but } \\
\text { rejected by } \\
\text { Hausman test }\end{array}$ & $\begin{array}{l}\text { Significant with high } \\
\text { R-square, preferred } \\
\text { by Hausman test and } \\
\text { time-fixed test }\end{array}$ \\
\hline 3 & $\begin{array}{l}\text { Significant but } \\
\text { very low } \\
\text { R-square value }\end{array}$ & $\begin{array}{c}\text { Significant but } \\
\text { low R-square } \\
\text { value }\end{array}$ & $\begin{array}{c}\text { Significant but } \\
\text { low R-square } \\
\text { value }\end{array}$ & $\begin{array}{c}\text { Significant but } \\
\text { low R-square } \\
\text { value }\end{array}$ & $\begin{array}{c}\text { Significant with } \\
\text { high R-square value } \\
\text { but rejected by } \\
\text { Hausman test }\end{array}$ & $\begin{array}{l}\text { Significant with high } \\
\text { R-square value and } \\
\text { preferred by Hausman } \\
\text { test and time-fixed test }\end{array}$ \\
\hline
\end{tabular}

As it can be seen from the table above, the most suitable model has been selected for the specific panel based on its significance, the R-squared value, and according to some statistical tests such as Hausman and time-fixed effects test.

Therefore, to summarize, for:

Panel 1, that is, the before crisis panel (1999-2007), the fixed LSDV model is used.

Panel 2, that is, the during/after crisis panel (2008-2016), the two-way random effects model is used.

Panel 3, that is, the long-run panel (1999-2016), the two-way random effects model is used.

Table 6. Overall summary of data analysis

\begin{tabular}{|c|c|c|c|c|c|c|c|c|c|}
\hline $\begin{array}{l}\text { PANEL ANALYSIS } \\
\text { MODEL }\end{array}$ & $\begin{array}{l}\text { Panel } 1(1 \\
\text { Fixed effe }\end{array}$ & $\begin{array}{l}\text { 999-2007): } \\
\text { cts with LSI }\end{array}$ & $\begin{array}{l}\text { Before Crisis } \\
\text { V Model }\end{array}$ & $\begin{array}{l}\text { Panel } 2 \text { ( } \\
\text { Two-way }\end{array}$ & $\begin{array}{l}\text { 008-2016): I } \\
\text { Random effe }\end{array}$ & $\begin{array}{l}\text { uring/After Crisis } \\
\text { cts model }\end{array}$ & $\begin{array}{l}\text { Pane } \\
\text { Two- }\end{array}$ & $\begin{array}{l}\text { (1999-2016) } \\
\text { y Random e }\end{array}$ & $\begin{array}{l}\text { Long-run } \\
\text { fects model }\end{array}$ \\
\hline $\begin{array}{l}\text { Independent } \\
\text { Variables (I.V) }\end{array}$ & Relation & Sig. of I.V & Sig. of model & Relation & Sig. of I.V & Sig. of model & Relat & Sig. of I.V & Sig of model \\
\hline HUR & $+\mathrm{ve}$ & No & Yes & $-\mathrm{ve}$ & Yes & Yes & $-\mathrm{ve}$ & Yes & Yes \\
\hline CPI & $-\mathrm{ve}$ & No & & $-\mathrm{ve}$ & Yes & & $-\mathrm{ve}$ & Yes & \\
\hline $\begin{array}{l}\text { GRANGER CAUSA } \\
\text { Causality Diagram }\end{array}$ & ITY TEST & & & & & & & & \\
\hline
\end{tabular}

\section{Findings and Discussion}

The table provided below represents a summary of the panel regression models chosen for the 3 panels.

Table 7. Panel data analysis models

\begin{tabular}{ll}
\hline Panel & Model \\
\hline 1 & Fixed effects with LSDV model \\
2 & Two-way random effects model \\
3 & Two-way random effects model \\
\hline
\end{tabular}


The reason why the three panels are significant for different models, despite having same countries, can be explained by the different time periods. For example, the time period for Panel 1 is that of before crisis (depression) whereas that of Panel 2 entails data during/after crisis. On the other hand, Panel 3 is subject to data before, and as well as during/after crisis, indicating a long-run time period. Thus, as explained earlier, the most suitable model has been selected for each panel. Based on their respective models, each panel will be interpreted.

\subsection{Model Interpretation for Panel 1}

For Panel 1, the fixed effects with LSDV model proved to be the most significant. The panel regression equation for Panel 1 is:

$$
\begin{gathered}
\text { GDPit }=(0.01775) \text { HURit }-(0.04918) C P I i t+(0.62747) A U T+(0.34621) D E U+(0.46578) F R A+(0.7031) \\
G B R+(0.92235) G R G+(1.1197) H U N
\end{gathered}
$$

where

- GDPit is the GDP growth rate for country, $\mathrm{i}$ at time, $\mathrm{t}$;

- HURit is the Unemployment rate for country, $i$ at time, $t$;

- $\quad$ CPIit is the Inflation rate for country, $i$ at time, $t$;

- Dummies (for countries): AUT is Austria, DEU is Germany, FRA is France, GBR is United Kingdom-UK, GRG is Greece and HUN is Hungary.

The following table summaries the significance of the variables and the dummies.

Table 8. Statistical results for panel 1 using fixed LSDV model

\begin{tabular}{lccc}
\hline Panel 1:Before Crisis Panel (Fixed LSDV) & P-values [Pr $(>|t|)]$ & Significance & Relationship \\
\hline HUR & 0.7205 & Insignificant & Positive \\
CPI & 0.1730 & Insignificant & Negative \\
Dummy for Austria & 0.0220 & Significant & Positive \\
Dummy for Germany & 0.4683 & Insignificant & Positive \\
Dummy for France & 0.3239 & Insignificant & Positive \\
Dummy for UK & 0.0157 & Significant & Positive \\
Dummy for Greece & 0.0920 & Significant & Positive \\
Dummy for Hungary & 0.0121 & Significant & Positive \\
\hline
\end{tabular}

As it can be seen from the Table 7, during the before-crisis panel, unemployment rate (HUR) and inflation rate (CPI) are not significant which implies that they do not have a significant impact on the GDP growth rate before the 2008 crisis in Europe. This is in line with the study conducted by Bruno and Easterly (1996) who found that the relationship between inflation rate and GDP growth is significant only during abnormal economic periods such as crisis. In the case of Panel 1, the variables are being studied in the period before crisis, where the European economy was doing "too well" to validate the relationship that is present between the economic variables GDP, unemployment and inflation.

Moreover, during boom periods of strong economic growth (GDP growth), unemployment rates do not affect the GDP growth rates because during boom periods, full employment is assumed, whereby households are hired and employed. Therefore, assuming full employment, this would imply that the unemployment rate is very low and insignificant. As a consequence, it would not be able to significantly affect GDP growth.

In addition, for the before-crisis panel, dummies for France and Germany are not significant. These can be explained by the fact that these two economies are among the largest and most influential countries in Europe, and thus in the European Union as well. Since these two countries are among the largest economies of the EU, in order for them to be significant in the before-crisis panel, they should be studied over a longer period.

The fixed effects LSDV model is significant for Panel 1, since the p-value of the F-test $(<2.2 \mathrm{e}-16)$ is less than 0.05. Thus, null hypothesis of the F-test is rejected and concluded that the LSDV model is significant with R2 of 0.546. It is consistent with the studies conducted by Levine (2013), Mallik and Chowdhury (2001), who have found that no significant relationship, in the short run, between unemployment and GDP, and inflation and GDP respectively.

\subsection{Model Interpretation for Panel 2}

For Panel 2, the panel regression equation for Panel 2 is: GDPit $=1.939+(-0.0352)$ HURit $+(-0.262)$ CPIit $+\lambda t$ 
where

- 1.939 is the intercept coefficient;

- GDPit is the GDP growth rate for country $i$ at time $t$;

- HURit is the Unemployment rate for country, $\mathrm{i}$ at time, $\mathrm{t}$ (with negative coefficient -0.0352);

- CPIit is the Inflation rate for country, $i$ at time, $t$ (with negative coefficient -0.262);

- $\lambda t$ represents the coefficient for the time factors. It is to be noted that $\lambda t$ has been used instead of a numerical figure, because for this Panel, almost all the time factors, from 2008 quarter 1 to 2016 quarter 2, are significant. Thus the $\lambda t$ represents the aggregated coefficients for time factors in Panel 2 model. The following table summaries the significance of the variables and the dummies.

Table 9. Statistical results for panel 2: Two-way random effects

\begin{tabular}{lccc}
\hline Panel 2:During/After Crisis Panel (2-way Random) & P-values $[\operatorname{Pr}(>|t|)]$ & Significance & Relationship \\
\hline Intercept & $2.030 \mathrm{e}-05$ & Significant & Positive \\
HUR & $0.036^{*}$ & Significant & Negative \\
CPI & $3.805 \mathrm{e}-06$ & Significant & Negative \\
$\lambda_{t}$ (Time-fixed effects) & $<0.05$ & Significant & Negative \\
\hline
\end{tabular}

As it can be seen from Table 9, for the during/after-crisis panel, HUR and CPI are both significant and time-fixed effects are significant, throughout the crisis period, and after the crisis as well. Moreover, the p-value for the $\mathrm{f}$-test of the model overall $=<2.22 \mathrm{e}-16$ and $\mathrm{R}$-squared value $=0.5536$.

\subsection{Model Interpretation for Panel 3}

For Panel 3, the panel regression equation for Panel 3 is: GDPit $=1.408+(-0.065)$ HURit $+(-0.0607)$ CPIit $+\lambda t$ where,

- 1.408 is the intercept coefficient;

- GDPit is the GDP growth rate for country, i at time, $\mathrm{t}$;

- HURit is the Unemployment rate for country, $\mathrm{i}$ at time, $\mathrm{t}$ (with negative coefficient -0.065);

- CPIit is the Inflation rate for country, $i$ at time, $t$ (with negative coefficient -0.0607);

- $\lambda t$ represents the coefficient for the time factors. It is to be noted that $\lambda t$ has been used instead of a numerical figure, because for this Panel, almost all the time factors during the crisis around year 2008, are significant. Thus the $\lambda t$ represents the aggregated coefficients for significant time factors in Panel 3 model.

Table 10. Statistical results for panel 3 using two-way random effects

\begin{tabular}{lccc}
\hline Panel 3:Long-run Panel (2-way Random) & P-values $[\boldsymbol{P r}(>|t|)]$ & Significance & Relationship \\
\hline Intercept & 0.0001443 & Significant & Positive \\
HUR & $2.643 \mathrm{e}-07$ & Significant & Negative \\
CPI & 0.0303 & Significant & Negative \\
$\lambda_{\mathrm{t}}$ (Time-fixed effects) & $<0.05$ & Significant & Negative \\
\hline
\end{tabular}

As it can be seen in Table 10, for the during/after-crisis panel, HUR and CPI are both significant and time-fixed effects are significant, particularly throughout the crisis period, and at some points after the crisis as well. Moreover, the $\mathrm{p}$-value for the F-test of the model overall $=<2.22 \mathrm{e}-16$ and $\mathrm{R}$-squared value $=0.51185$.

The results of the two-way random effects model both for Panel 2 and 3 indicates that both unemployment rates (HUR) and inflation rates (CPI) each have a negative significant relationship with GDP growth rates during/after the 2008 European crisis.

The negative relationship between unemployment rate and GDP growth rate is in line with the well-known theory of Okun's law, who states an inverse relationship between the 2 variables. This has been previously explained in the theoretical literature review section. This result is also consistent with the panel data analysis by Uz, Donghui and Imran (2012) that used a sample of 13 European countries for the years 1993 to 2012 and methods such as Pooled OLS and Fixed effect in their research, concluded that GDP per capita is negatively and 
significantly affected by higher unemployment rates.

The same conclusion has been drawn by Alias et al. (2011). The significant negative relationship between unemployment rate and GDP growth rate during/after the crisis can be explained due to the fact that during such bad economic periods, many workers are made redundant (causing unemployment to increase). Consequently, this contributes to a fall in the productivity level of workers, together with a decrease in aggregate demand by consumers (given that they have less to spend and prefer to save during recession) and thus causes the GDP growth to drop. Thus, as it can be deduced, one unit increase in unemployment rates causes the GDP growth rate to fall by $-0.0352 \%$ according to Panel 2 results (during/after crisis) or by $0.065 \%$ according to Panel 3 results (in the long-run).

In addition, the negative relationship between inflation and GDP growth rate during crisis period and post-crisis period is consistent with other studies conducted by Alias et al. (2011), David et al. (2005), Mamo (2012) and Makuria (2013). These researchers found that strong negative relationship between inflation and GDP growth rates in longer run period and in periods when inflation rates are changing drastically. This is therefore in line with the findings of the research, because Panel 2 and 3 examine these 2 variables during drastic periods such as the 2008 European crisis. The significant negative relationship between inflation rates and GDP growth rates can be explained by the fact that during crisis period, because aggregate demand of goods and services are fairly low, firms have the tendency to cut down prices, leading to a fall in the inflation rate. As a result of decrease in prices, aggregate demand increases again, causing GDP growth to increase.

During the periods of crisis, or even after, if inflation rate increases (price increases), households will drastically reduce their demand of goods and services. This denotes the significant negative impact of inflation rate over GDP growth rate during/after crisis, and as well as in long run. Thus, as it can be deduced, one unit increase in inflation rates causes the GDP growth rate to fall by $0.262 \%$ according to Panel 2 results (during/after crisis) or by $0.0607 \%$ according to Panel 3 results (in the long-run).

For both Panel 2 and Panel 3, time-fixed effects are significant, mostly during the crisis period in 2008. These can be explained due to the fact that the 2008 European crisis is marked as a significant event that touched the different economies in Europe. Therefore, it is evident that the time-fixed effects applied in the model are highly significant during the crisis years.

\subsection{Granger causality}

Granger causality test has also been conducted for the 3 panels of the data set to find the causal relationships between each of the variables in this study.

\subsubsection{Granger Causality Panel 1}

For the before crisis panel, the granger causality test found that there is a bidirectional relationship between CPI and GDP and a unidirectional relationship between HUR and GDP (where GDP granger-cause HUR). For Panel 1 , during boom period, the reason behind the two-way causality between GDP and CPI is that an increase in growth rate during this period might cause an increase in inflation. An increase in inflation rate will, at its turn, trigger a decrease in GDP growth rate, due to the reduced demand of goods and services after rise in price. Moreover, the reason behind the one-way causality between GDP and HUR is that before crisis, when the economy is within the boom period, an increase in GDP growth rate will cause a decrease in unemployment rate. On the other hand, during boom period, a fall in unemployment rate will not cause an increase in GDP growth rate, because during this period, the economy is already at its maximum efficiency point.

\subsubsection{Granger Causality Panel 2}

For the during/after crisis panel, the granger causality test found that there is a bidirectional relationship between HUR and GDP and no granger causality between CPI and GDP. For Panel 2, during/after crisis period, the reason behind the two-way causality between GDP and HUR is that a decrease in growth rate during this period might cause an increase in unemployment. An increase in unemployment rate will, at its turn, trigger a decrease in GDP growth rate, due to the smaller purchasing power on behalf of households and hence reduced demand of goods and services. Secondly, the reason behind no causality between GDP and CPI is that particularly during crisis, the inflation rate is subject to drastic changes. So, in this case, no significant relationship can be established between the 2 variables.

\subsubsection{Granger Causality Panel 3}

For the long-run panel, the granger causality test is consistent with that of the before-crisis panel (Panel 1); whereby there is a bidirectional relationship between CPI and GDP and a unidirectional relationship between 
HUR and GDP (where GDP granger-cause HUR). For Panel 3, during the long-run period, the reason behind the two-way causality between GDP and CPI is that an increase in growth rate might cause an increase in inflation, due to the increased demand of goods and services. And, an increase in inflation rate will, at its turn, trigger a decrease in GDP growth rate, due to the reduced demand of goods and services after rise in price. This would depend where exactly the time period being observed, is on the economic cycle.

Then, the reason behind the one-way causality between GDP and HUR is that in the long-run, , an increase in GDP growth rate will cause a decrease in unemployment rate, because more workers will be needed. And on the other hand, in the long run, a fall in unemployment rate will not cause an increase in GDP growth rate, because during this period, the economy is assumed to be fully efficient.

\section{Conclusion}

As highlighted in the study, GDP growth rates, inflation rate and unemployment rate are important economic and statistical indicators for government actors, investors and amongst others. Therefore, determining the relationship between these variables is important. Very few researchers focused the area of their research on the relationship of these variables before and after the 2008 European crisis. Hence, so as to eliminate the presence of any kind of uncertainty and doubts, this study has been brought to light, to get a better picture of the impacts of the financial crisis on the relationship of the suggested variables of this study.

The two independent variables (unemployment rate and inflation rate) and the dependent variable (GDP growth rate) have been considered for a panel of 6 sample countries over 18 years of quarterly data (including the EU crisis). The 6 countries include Austria, France, Germany, Greece, Hungary and Great Britain (UK). To analyze the effect of the European crisis, based on the previously mentioned independent and dependent variables, the panel data set was classified in 3 parts. These are firstly, Panel 1 (1999-2007), also known as the before crisis panel; secondly Panel 2 (2008-2016), also known as during/after crisis panel; and lastly, Panel 3 (1999-2016), entailing data before and after crisis, also known as long-run panel.

After all the assumptions were tested, different panel regression analysis models were executed for each panel. Then, the most significant model has been chosen for each panel. The most suitable model for Panel 1 was found to be the fixed effects with LSDV model. The most appropriate model for both Panel 2 and Panel 3 were found to be the two-way random effects model.

The panel regression model for Panel 1 revealed that before crisis, neither of the independent variables (HUR and CPI) has a significant relationship with the dependent variable (GDP). However, dummies added for the countries were significant for Austria, Greece, UK and Hungary. The panel regression model for Panel 2 and Panel 3 had almost similar results, with a significant negative relationship between HUR and GDP, and between CPI and GDP. These results were interpreted and supported by the past studies.

\section{References}

Alias, T. S., Razak, E. A. A., Asari, F. F. A. H., \& Zin, S. M. (2011). Multivariate Time Series Analysis on Correlation Between Inflation Rate and Employment Rate with Gross Domestic Product.

Baltagi, B. (2008). Econometric analysis of panel data (4th ed). Chichester: John Wiley \& Sons Inc.

Cuaresma, J., \& Silgoner, M. (2013). Economic Growth and Inflation in Europe: A Tale of Two Thresholds.

Dapontas, D. (2011). Currency crisis: The case of Hungary (2008-2009) using two stage least squares. Special conference paper, bank of Greece, Eurosystem.

Data.worldbank.org. (2017). Data, The World Bank.

David, D., Pedro, G. P., \& Paula, H. E. (2005). Threshold effects in the relationship between inflation and growth: A new panel-data approach.

European Commission. (2009). European Commission-Economic and Financial affairs.

Fletcher, N., McDonald, H., \& Kasperkevic, J. (2016). Eurozone economic growth slows, while US GDP disappoints - as it happened. The guidance.

Gillman, M., Harris, M. N., \& Matyas, L. (2001). Inflation and growth: Some theory and evidence. 10th International Conference on Panel Data, Berlin, July 5-6, 2002 D5-1, International Conferences on Panel Data. https://doi.org/10.2139/ssrn.268139

Göçer, I., \& Erdal, L. (2015). Retrieved $\quad$ February 9, 2017 from http://iibfdergi.karatekin.edu.tr/Makaleler/477766409_JFEAS_5_1_10.pdf 
Makuria, A. G. (2014). The relationship between inflation and economic growth in Ethiopia (Doctoral dissertation).

Mamo, F. (2012). Economic growth and Inflation: A panel data analysis.

McMahon, T. (2017). InflationData: Inflation and Recession.

Neto, A., \& Silva, S. (2013). Growth and Unemployment: A bibliometric analysis on mechanisms and methods. FEP Working Papers 498, Universidade do Porto, Faculdade de Economia do Porto.

Uz, Z. Q., Donghui, Z., \& Imran, M. (2016). European Journal of Economic Studies, 15(1), $292-298$. https://doi.org/10.13187/es.2016.15.292

Zagler, M. (2003). The Dynamics of Economic Growth and Unemployment in Major European Countries: Analysis of Okun's Law.

\section{Copyrights}

Copyright for this article is retained by the author(s), with first publication rights granted to the journal.

This is an open-access article distributed under the terms and conditions of the Creative Commons Attribution license (http://creativecommons.org/licenses/by/4.0/). 